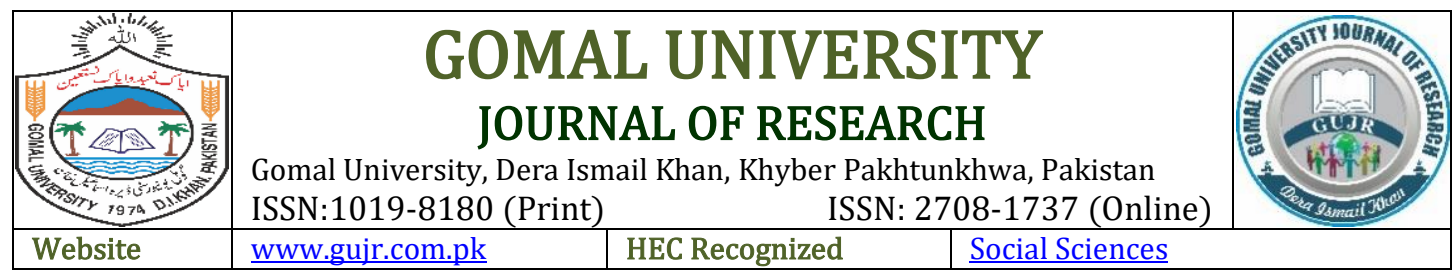

\title{
PAKISTAN-TURKEY RELATIONS DURING COLD WAR DECADES: BEYOND RELIGION AND CULTURAL DIMENSIONS
}

\author{
Rahat Shah \\ The School of International \& Public Affairs, The Jilin University, Changchun, CHINA
}

\section{ARTICLE INFO $\quad$ ABSTRACT}

Keywords:

Pakistan, Turkey,

Ottoman Empire,

Pakistan-Turkish, Cold

War, Kashmir, Cyprus,

Friendship Treaty

Article History:

Date of Submission:

13-01-2020

Date of Acceptance:

18-12-2020

Date of Publication:

$31-12-2020$

This study explores the bilateral relationship between Pakistan and

Turkey during the Cold War, in which the bilateral relationship had developed gradually. To understand why it had developed? We must transcend cultural and religious factors. The study argues that the development of bilateral relations was mainly due to the interest of the Western Allies and the strategic consensus between Islamabad and Ankara. Although the Cold War was dominated by bipolarity, in which two superpowers pursued their power and influence globally including the Middle East, it is by no means that other regional powers acted nothing role. Turkey had played a central role in getting Pakistan to join the regional pact, which was in West's strategic interest. Besides, Pakistan and Turkey stood out prominently in terms of the strategic consensus since 1965. Strategic consensus between them has helped to forge cooperation on key issues such as Kashmir and Cyprus. Our analysis shows that relationship between the two countries was caused by these two factors, in which cultural and religious factors are either ineffective or have little impact.

\begin{tabular}{|c|c|}
\hline & (c) (i) (8) 2020 Gomal University Journal of Research \\
\hline Corresponding Author & Rahat Shah: Rahatshah8@gmail.com \\
\hline DOI & https://doi.org/10.51380/gujr-36-02-04 \\
\hline
\end{tabular}

\section{INTRODUCTION}

This study aimed to explore the bilateral relationship between Pakistan and Turkey during the Cold War, as the relationship between the two countries has developed gradually over the past few decades (Shah \& Wang, 2020). In order to explain steady development of bilateral relations, this study goes beyond cultural and religious factors and argues that this is mainly due to the interests of the Western Allies and strategic consensus between Islamabad and Ankara. In this case, for example, the US had hoped to link Pakistan to a regional defence agreement in which it needed Ankara's support to persuade Islamabad. Because of this, Islamabad and Ankara drew closer and signed a treaty of friendship in 1954 (Shah, 2020). Ankara, however, was reluctant to do so at the expense of India and Afghanistan. The two countries later joined the Central Treaty 
Organization (CENTO) in 1955. Besides, both states stood out prominently in terms of strategic consensus since 1965. The strategic consensus between two Muslim powers helped forge their cooperation on the fundamental issues such as Kashmir and Cyprus. These were their national interests, as Morgenthau, the founder of the realism theory, describes, "Interest is the perennial standard by which political action must be judged and directed, objectives of foreign policy must be defined in terms of the national interest" to safeguard state interests (Horus Administrator, 2014).

\section{LITERATURE REVIEW}

In light of the existing literature on Pakistan-Turkey relations, no major study has thus moved beyond the cultural and religious dimensions. Ergo, this paper fills this gap and provides the first comprehensive overview of the relationship between Pakistan and Turkey during the Cold War. This paper first introduces the relations between Pakistan and Turkey before 1953, then expounds on the development of relationship until 1965, and at that point strategic consensus of two states (Pakistan \& Turkey) on the Kashmir and Cyprus since 1965 (Horus Administrator, 2014). The data obtained through existing sources provide sufficient understanding about the relationships between Pakistan and Turkey in terms of the strategic relations and cultural and religious perspectives to highlight the different perspectives that are functional in background of bilateral relationship (Ahmed, Qadri \& Ahsan. 2016). The new journey of the Pakistan-Turkey relations started when Pakistan emerged as an independent state of the world wherein Turkey recognized sovereignty of Islamabad (Shah, 2020). This relationship give birth to an undaunted association between Pakistan and Turkey in the globalizations concerning religious and cultural diversities that are actively functional and effective operative in the background of the bilateral relationships.

In order to address the significance of study, diverse literature is carefully reviewed, but limited literature was available that covered the Pakistan-Turkey relations during the Cold War era. No writing has moved beyond the religious and cultural factors. Muhammad Qadri explained PakTurco relations in the context of a common culture, geopolitical concerns, and political interests. He described that both the states' relationships have enhanced with time due to their historical linkages with each other. Colakoglu and Sakaoglu (2016) argued that both states' relations are due to common identity which is shaped by cultural and religious factors. Farrukh and Ali (2012) has explained the Pak-Turkey relations in the term of economic interests related based by other vital issues. Hussain (2018) argued that both states' relationship is due to commonalities such as historical, religious, and cultural. Ahmad (1981) also described relations in terms of cultural and historical perspectives. Zubeida (1964) also neglected the underline question. The literature revealed that Turkey played significant role to convince Pakistan to become the part of regional defense pact. Thus, this paper is expected to go beyond these factors and fill existing gap in research about Pak-Turkey relations, which may be great contribution to existing database of knowledge.

\section{RESEARCH METHODOLOGY}

This paper uses qualitative methods to the collect data like literature review, published contents, and historical events related to this topic. The secondary data has been collected from foreign policy documents, such as speeches by national leaders and other officials. Secondary data was collected from international relations journals, books, and newspapers relevant to our subject. This article uses international relational databases such as Taylor \& Francis Online, JSTOR, and 
Google Scholar. Moreover, it uses journals related to Pakistan and Turkey like Strategic Studies, Pakistan Horizon, Turkish Studies, and Third World Quarterly. Also, articles and editorials from Pakistani newspapers, such as Dawn and Tribune Express, and Turkish newspapers such as the Hürriyet Daily News, the Shaba daily, and the Turkish Anadolu News Agency were utilized to extract the desired data and information about the Pakistan and Turkey relationships in diverse circumstances.

\section{RESULTS \& DISCUSSIONS}

The argumentations of various analysts yielded powerful result that both state relations are due to the Western allies' interest and strategic consensus of Pak and Turkey on the Kashmir and Cyprus issue. Our arguments give us an in-depth and complete picture of Pak-Turco relations. We find that cultural and religious factors either have no effect or have little effect. The exploring of this problem was significant to well-understand both state relations in the context of these two factors. Furthermore, the study made the significant contribution, as various theories of the International relations can be applied to it to conduct further research on same topic around the globe.

\section{Evolution of Relations Until 1953}

In 1947, Pakistan became an independent sovereign state in the world, where Turkey recognized the sovereignty of Islamabad. The new journey of Pakistan-Turkey relations commenced with the nomination of Yahya Kemal as the first ambassador to Pakistan. He was a former imperial official at the court of the Ottoman Empire; this episode indicated that Turkey paid sufficient attention to bilateral relations with Pakistan from the very beginning. The great leader, lawyer, and founding father of Pakistan Quaid-e-Azam Muhammad Ali Jinnah welcomed Yahya Kemal and attached importance to both states' ties. He hoped that relations between the two countries would be further strengthened through certain policies and actions based upon the interests of both the countries. He appreciated his experience and mentioned in the first meeting that, "your Excellency has yourself observed that many spiritual and sentimental ties, born and grown in the course of a long history, bind the people of Turkey to the people of Pakistan" (Tanvir, 2011). In the early days of independence, Pakistan used the Indian-British currency printed with the word "Pakistan". In 1949, Islamabad launched its own currency, but due to an insufficiency of capabilities, they faced difficulties in printing process where Turkey helped them in the printing process (Farrukh \& Ali, 2012). Next, both states came closer to each other due to the formation of the regional defense agreement against communism that was the basic interest of the United States.

\section{Development of Relations Until 1965}

Until 1965, the development of Pakistan-Turkey relations was mainly based on the interests of Western allies. In 1953, the second phase of their relationship commenced with the formation of the regional defense pact. The West was needed both states' support to accomplish its own interests. Particularly, it was interested to link Pakistan to the regional defense pact, but due to Kashmir and Indian factors, it was a little difficult for Washington to do so directly. On the other hand, Turkey was also reluctant to help and provide military support to Pakistan at the expense of Kabul and New Delhi. Despite this, due to West allies' interests, Turkey played a significant role to convince and make Islamabad part of regional defense pact. Pakistan was strategically indispensable to Western allies in Middle East affair, for instance, geographically it is situated at the entrance of the Gulf of Oman, and coastline of the Strait of Hormuz touching the Indian 
Ocean. Second, the "armed forces of Pakistan are numerically largest among the members of the Middle Eastern region due to many reasons, perhaps with the exception of Turkey" (CSFH, 1989).

In May 1953, Dulles visited Pakistan where he met with Prime Minister of Pakistan Mohammed Ali and expressed the West point of view regarding the security of the Middle East. He said that we need Pakistan to support us in joining regional pact against communism in the region. Both are agreed though Pakistan was concern regarding the Indian threat and wanted to enhance its own security capabilities. During the Dulles discussion on Pak-India's situation, Mohammed Ali said that a signal must come from Jawaharlal Nehru and that pressure must be brought to bear on Nehru to achieve a solution. He said that the United States must keep the heat on both of us (FRUS, 1986). The situation was difficult to convince Pakistan, as we know, "no matter how much leverage you hold over a country, it is rare that you can get it to act against its core selfinterest" (Dimitrakis \& Panagiotis, 2009). On 26 May, Dulles met with the Prime Minister of Turkey, Adnan Menderes, and discussed the situation and requirements of the regional pact wherein the interest remained on the main issues. Prime Minister Adnan said that Turkey would do its best for the interest of the West to convince Pakistan to join the regional Treaty (FRUS, 1986).

As mentioned earlier that Pakistan would join the defense pact, only if United States provides military and economic aid to it. However, Washington was unwilling directly to do so, because it was facing complications to give aid to Islamabad directly, as the US President Richard Nixon mentioned that the Prime Minister of India Jawaharlal Nehru has concern over the US aid to Pakistan. The Islamabad will use this aid against India and will strengthen its position over the Kashmir issue (2001). Ergo, the West attempted to bring Pakistan and Turkey closer to achieve their own hidden and unhidden interest without making India unhappy. However, same as the West, Ankara was not willing to because in reality it not wanted to make India and Afghanistan unpleasant.

In September 1953, Gen Ayoub Khan paid a visit to Turkey, to discuss the situation but Ankara did not seem to be interested as it noted during Ayoub khan visit:

He was impressed generally with the Turkish military posture, but he found no disposition on the part of Turkish government to talk about substantive matters of regional defence. The only cabinet member he met was Minister of Defence, who did not impress him. He did not meet President, Prime Minister, Foreign Minister, all of whom were not available. The Nuri Birgi, Under Secretary General of Turkish Ministry of Foreign Affairs, expressed a favourable personal reaction to idea of close Turco- Pakistani defence collaboration, but added that base would have to be very carefully laid. He said that Turkish government wanted to be sure that Pakistan objective was not to use Turkey against India (Yeşilbursa, 2001).

In order to bring Turkey and Pakistan closer to each other for the sake of to achieve his interest thus:

On 24 December 1953, Dulles instructed the American Ambassador in Ankara to tell the Turkish government of the proposed military aid for Pakistan, and to suggest that the Turkish government should take the lead in approaching the Pakistani government to start military talks concerning a mutual defence arrangement for the best interest (NNK, 2001). 
Therefore, Turkish leaders paid visit to Pakistan along with the agenda of Washington (Sanjian, 1997). In January 1954, Turkish agreed to provide military assistance to Pakistan by mentioning that:

Turkish government indicated that it would give what assurances it could: for instance, Turkey would not take sides between Pakistan and India as regards the Kashmir dispute and nor to take side over Pakhtoonistan due to internal issues linked with peace (Yeşilbursa, 2001).

Turkey stated that they would not take the side of Islamabad against New Delhi and Kabul as both states have territorial disputes with Islamabad. Pakistan agreed, and in this context, they signed the Treaty of Friendship cooperation on April 2, 1954 (FRUS, 1986). The House Foreign Affairs Committee and American Secretary Dulles attached importance to the treaty is the good development toward mutual security and prospects of region (1990). Moreover, Turkey showed his interest to band and invest in Pakistan arm defense industries. As per article 4 Friendship Treaty:

Consultation and cooperation between the contracting parties in the field of defence shall cover the following points: (a) Exchange of information for the purpose of deriving joint benefit from technical experience and progress, (b) Endeavors to meet, as far as possible, the requirements of the parties in the production of the arms and ammunition in (CSFH, 1989).

The reason behind this willingness of Ankara was due to the West allies' interest, as mentioned earlier that although Turkey was not happy to do so, which is also stated by representative of British.

According to Scott Fox, the Counsellor at the British Embassy in the Ankara, the Turkish government was anxious to play down the military aspect of their talks with Pakistan, and would be likely to emphasize political nature of the talks in the joint communiqué (NNK, 2001).

In September 1955, Pakistan also became a member of the Baghdad Pact due to the invitation of Turkey (Baghdad Pact, 1956). However, in 1958, due to revolution in Iraq, this pact dissolved, and it headquarter shifted to Ankara with new name the Central Treaty Organization (CENTO). First time under this organization, the microwave radio link was established calling AnkaraTehran-Karachi radio to sustain communication between these three countries (1960). When both states disappointed with CENTO, then in 9164 they established distinct political institution outside of the CENTO, calling Regional Cooperation Development (RCD) to obtain particular objectives.

\section{Strategic Consensus Since 1965}

Pakistan and Turkey, which are the two of the most powerful countries of the Middle East and the Muslim world, stood out prominently in terms of the strategic consensus since 1965. The strategic consensus between two Muslim powers helped forge their cooperation on key issues such as Kashmir and Cyprus. Throughout the Cold War era, Ankara has supported Islamabad on the Kashmir issue. Kashmir is Pakistan's national interest and occupies an important place in its foreign policy. Islamabad considers Kashmir is a part of the Islamic Identity and backbone, and without it, Pakistan could not survive even for a while. The issue of Kashmir goes back to 
the British Empire's decision that Kashmir is free to join either Pakistan or India. Principally, the two-nation theory and geographical contiguity support that Kashmir belongs to Pakistan. Gen Zia and Zulfiqar Bhutto had motioned in UN Security Council that, "the people of Jammu and Kashmir are part of the people of Pakistan in blood, in flesh, in life, in culture, in geography, in history and every way and in every form If necessary, Pakistan would fight to end" (Pattanaik, 2002).

Islamabad had tried to influence world public opinion in their favor by raising issue in various forums, especially at Muslim platform. Pakistan has attached worth to third party mediation role and debates Kashmir issue on bilateral and multilateral forums. In words of Lt. Gen. K. M. Arif:

To keep the issue alive, Kashmir must- hit the headlines in the press and electronics media in West... My suggestion is that we should project India as a usurper of human rights so as to safeguard the general intrests. India should be portrayed as an occupation force, a country which is holding Kashmiris against their will. We should portray India hurting minorities. Kashmiris are suffering as they occur to be Muslims in Hindu state (Pattanaik, 2002).

Kashmir is the national interest of Pakistan, and since independence, over this issue; Pakistan and India have fought four wars. However, Islamabad realized that war is not solution to this problem and needs to be highlighted on bilateral and multilateral forums, and support of other states is needed. Thus, Ankara was the one who always stands with Islamabad on this issue. As the situation changed during the Cold War era, Islamabad gradually disappointed with CENTO on Kashmir issue. Pakistan was needed the support of Muslims and other countries to highlight this issue on every forum where Turkey has no exception. Islamabad and Ankara both have had concerned with particular Cyprus and Kashmir issue, and both states are supporting morally and politically each other that bring them closer to each other time by time. In 1956, relations strengthened when both states' interests converged about Cyprus and Kashmir's issue. Ankara and Islamabad ensured that to support each other politically and morally on these issues (1981). This policy to defend each other on a particular issue brought a new turning point in both states' relationship. As mentioned until 1956, Turkey was not willing to support Pakistan over Kashmir issue.

During second war between Pakistan-India in 1965, Turkey showed his support for Islamabad and declared India as aggressive state. This support strengthens Pakistan security and integrity. During an interview of Major General Tajammul Hussain who had fought that war in 2001 said that:

A vast majority of Turks are dedicated Muslims and have very good feelings towards the Pakistan. In the 1965 war, Prime Minister of Turkey had ordered all resources of Turkish Armed Forces to be placed at the disposal of Pakistan and anything they need must be immediately provided. Both armies were equipped with American equipment, planeloads of ammunition and equipment were sent to Pakistan to meet our requirements. Through my stay in Turkey, I felt as if I was at home. I with my family traveled throughout the country, and at the no stage, I ever felt that I was in the foreign land (Elman \& Michael, 2014).

In September 1965, during the war with New Delhi, the Prime Minister of the Turkey issued a statement condemning Indian hostilities and said that: "therefore, suffering felt by Pakistanis 
are shared by the Turkish nation" (1989). Further, on certain occasion on 10 September 1965, Ankara and Tehran had held the joint meeting for an immediate ceasefire and thus concluded that:

The Governments of Turkey and Iran reaffirmed the solidarity which links Turkey, Iran, and Pakistan, and declared that they are ready to support Pakistan, a brother country, and ally. Turkish Premier declared that Turkey would send 5-million-dollar worth of Turkish made arms and ammunition to Pakistan under terms of existing trade agreement (Ahmad, 1981).

Turkey had shown his stance when US and its allies postponed the Consortium aid to Pakistan in July 1965. The Turkish Foreign Minister, Hassan Isik motioned, in July 1965, that Ankara was not happy with this behavior or Washington and his allies (Ahmad, 1981). On 2 April 1969, Turkish Cevdet Sunay sure new Pakistan government President Agha Muhammad Yahya Khan that:

Our two countries have extended their support and understanding of one another's problems at their most difficult periods. I would like to reaffirm to Your Excellency that Turkey will continue to extend its support to Pakistan in the future as well (Documents, 1969).

Both states relations further strengthened at the occasion of the 1971 war, when the 3oth Prime Minister of Turkey, Nihat Erim, standby Islamabad and said that the behavior of India is against the sovereignty and it should withdraw its forces from Pakistan. Referring to international law, he said: "principles of respect for independence and territorial integrity and non-interference in the international affairs of others should constitute the basis of international life" (Ahmad, 1981).

Even this support was confirmed before the initiation of the crisis, as on 28 November 1971, the Turkish Foreign Affairs Minister Osman Olcay was visited Pakistan and stayed until 1 December 1971. He affirmed in Karachi that we were strongly opposed to Indian interference in domestic affairs of Islamabad, and further, we will extend our support in case of Indian aggression (1971). As of November 28, Indian Prime Minister Indira Gandhi has warned Pakistan. He motioned his country's diplomatic initiatives on Pakistan-India crisis, that Turkey has dragged attention of international community toward resolution of hostilities between these two states. Referring to 1965 crisis, said that Indian action was a violation of UN Charter (1971). President of Pakistan, Zulfikar Ali Bhutto, acknowledged this stand during his visit to Turkey in January 1972; he thanked support and diplomatic initiative of Ankara for Islamabad during the Pak-India crisis (1971).

In November 1985, Pakistan President, General Zia-ul-Haq, invited Turkish President, Kenan Evren, and he paid three days visit to Islamabad. The joint communiqué was published, and both presidents expressed their concern over international matters where they agreed to bolster each other on regional peace and security issues. The Turkish President also appreciated and supported the initiation of Islamabad toward New Delhi to normalize the bilateral tens in their relations (1985). During the visit of the President Leghari and Nawabzada Nasrullah Khan, the President of Turkey agreed and joined the Working Group on Kashmir. The Turkish President Süleyman Demirel stated that the trouble of Islamabad is the trouble of Ankara. In response, Pakistan also assured that the problem of Ankara is the problem of Islamabad (2001). In this 
way, both states have morally and politically supported each other on their respective issues and problems.

Same as Kashmir, the Pak-Turco relationship cannot be explained without looking at the Cyprus issue. Same like Pakistan, Turkey also had steadily needed support of Islamic states about the Cyprus issue, where Islamabad has always supported it. Giving to Zurich-London agreements, Cyprus got independence in 1960 and was members of both groups such as Greek and Turkish Cypriot. This government collapsed, and in 1963, crisis started. "Greek Cypriots called this 'a withdrawal' and Turkish Cypriots” (Göktepe, 2005). The Crisis goes back to date 1955 when the analyzed:

Greek Cypriot enosis struggle assumed form of armed insurrection led by EOKA (National Organization of Cypriot Fighters), and in 1958, Turkish Cypriots set up their own armed organization, TMT. Greek Cypriots strove for enosis, the union of Cyprus with the Greece, while Turkish Cypriots initially expressed a preference for the continuation of British rule and the later demanded taksim, the partition of the said island (Papadakis, Nicos \& Gisela, 2006).

Whenever Turkey was needed international support about it, Pakistan had always supported them, morally, and politically on the Cyprus issue. For instance, in 1954 and 1957, the Islamabad helped Ankara over this issue in the General Assembly of the United Nations. The support of Turkey over Cyprus became part of Pakistan Constitutions. One can analyze the support of the Islamabad for Cyprus after critically reading and analyzing the constitutions of Pakistan such as:

The "Principles of Policy" sections in all three constitutions of Pakistan $(1956,1962,1973)$ have stated that Pakistan must make special efforts to develop its relations with Muslim countries. Nations like Lebanon and Cyprus have central bonds within policy framework of Pakistan's national sentiments that cannot be ignored; because of legislative mandate, establishment of relations with these countries became a constitutional necessity (CSFH, 1989).

Pakistan always support Ankara, for instance, in 1963, Foreign Minister of Pakistan Mohammad Ali Bogra supported and articulated his concern over President Makarios's decision to restrain the constitutional rights of Turkish minority in Cyprus (1966). He said that "we are with Turkey in her moments of crisis and whenever cooperation may be needed from Pakistan [it] will be extended in the fullest measure" (1989). Besides, during the Cyprus crisis in July 1974, Pakistan supported Turkey and assured to provide moral and material support. From the UK point of view, the alliance "was not involved in the conflict, but Pakistan and Iran were helpful [toward Turkey] and may well offer further moral and material support in any future Turkish quarrel with Greece" (Kaplan, 2009). In May 1975, Pakistan's Minister of State, Aziz Ahmed paid an official visit to Turkey as Turkish Minister Foreign Affairs, Ihsan Sabri Caglayangil was invited him. Director-General in the Ministry of Foreign Affairs, Mansur Ahmed, was with Aziz Ahmed. Both met with President Fahri Koruturk and Suleiman Demirel Prime Minister of Turkey. After mutual discussion, they issued a joint communiqué, and distinctive focus was attached to the Cyprus issue. Pakistan expressed his enthusiasm to support morally and politically Turkey over Cyprus.

Besides, Islamabad also suggested to Ankara that to resolve issues bilaterally (1975). Islamabad always standby Ankara on the Cyprus issue, throughout the cold war period. In November 1979, 
Pakistan politically supported Turkey and cost vote against UN decision during United Nations General Assembly resolution 34/30 on Cyprus (1979). In Nov 1983, Pakistan had expressed sympathy for declaration of Cypriot. It cost vote against the decision of the UN Security Council regarding Turkish Cypriots, and rejected Security Council call for the world that not to recognize declaration of an independent republic by Turkish Cypriots. Finally, Security Council accepted the objection of Islamabad and removed phrase "intercommunal negotiation" to achieve "a just and lasting settlement in Cyprus" from draft. "The Pakistani representative at United Nations, S. Shah Nawaz, urged the Council not to overlook the "complicated and tragic background" of the Turkish Cypriot action" (1983). On November 1985, as mentioned earlier during the visit of the Turkish President to Pakistan, upon the question of Cyprus president of Pakistan made sure that:

Pakistan supported the Turkish stand that best means of achieving an early and peaceful solution to question of Cyprus would be through direct talks between the representatives of Greek and Turkish-Cypriot communities. A mutually acceptable solution would ensure establishment of independent sovereign bi-zonal, bi-communal Federal Republic of Cyprus (1985).

In July 1986, the Prime Minister of Pakistan Muhammad Khan Junejo paid a visit to Ankara and reaffirmed the firm support of Islamabad as he mentioned that "Pakistan's support for the establishment of the independent, sovereign, bi-zonal bi-communal, the Federal Republic of the Cyprus" (1989). These were both states' national interests for which they supported each other for their best interests. These policies strengthened Pakistan-Turkey relations throughout Cold War.

\section{CONCLUSION}

The relationship between Pakistan and Turkey during the Cold War was mainly because of the interests of Washington and later because of the strategic consensus between the two countries since 1965. For example, the United States was wanted to link Pakistan to a regional defense agreement in which United States needed the support of Ankara to convince Islamabad. In this context, Islamabad and Ankara got closer and signed a Treaty of Friendship in 1954, despite Ankara's reluctance to do so at the expense of India and Afghanistan. The following year, both states became part of a U.S.-led regional defense Pact called CENTO. Next, since 1965, both states stood out prominently in terms of strategic consensus. The strategic consensus between the two Muslim powers helped forge their cooperation on key issues such as Kashmir and Cyprus. Throughout Cold War, two countries supported each other politically and morally on these issues, which has become the basis of today's relations between the two countries. Without these important factors, which have been ignored in other studies, we would not be able to analyze relationship between the two countries, so our argument has produced strong results. In contemporary period, there is a need for specific strong bilateral institutions over Kashmir and Cyprus issues, where both states policymakers conduct research on these issues and find solution.

\section{REFERENCES}

Sanjian, A. (1997). The Formulation of the Baghdad Pact, Middle Eastern Studies, 33 (2): 231. Baghdad Pact. (1956). International Organization, 10 (1): 212-213. 
Yeşilbursa, B. (2001). The American Concept of the 'Northern Tier' Defence Project and the Signing of the Turco-Pakistani Agreement, 1953-54, Middle Eastern Studies, 37(3): 77,73, $78-80,87$.

Chapter Syed Farooq Hasnat (CSFH). (1989). Pakistan's Vital Environment: The Middle Eastern Region. In Beyond Afghanistan: The Emerging U.S.-Pakistan Relations, Leo E. Rose and Kamal Matinuddin. Berkeley, University of California: pp. 232, 243,241,288229,240 .

Elman, C., \& Michael, A. J. (2014). Realism Reader, London and New York, Routledge Taylor \& Francis Group.

Göktepe, C. (2005). The Cyprus Crisis of 1967 and Its Effects on Turkey's Foreign Relations', Middle Eastern Studies, 41(3): 431.

Documents. (1969). Pakistan Horizon, 22(2): 193.

Dimitrakis, S., \& Panagiotis, P. (2009). British Diplomacy and the Decline of CENTO. Comparative Strategy, 28(4): 321.

Farrukh, S., \& Ali, W. (2012). Recent Trends and Prospects of Bilateral Trade between Pakistan and Turkey: A Gravity Model Approach. Journal of International and Global Economic Studies, 5 (1): 57-72.

FRUS. (1986). 1952-1954, The Near and Middle East, Volume IX, Part 1, Document 42.

Horus Administrator. (2014). 1965 War - Turkish war resources were placed at Pakistan's disposal', Pakistan Defence.

Ahmed, M. Q., Qadri, S., \& Ahsan. L. (2016). Comparative Study of Local Government with Reference to Pakistan and Turkey Relationship. Developing Country Studies, 6(3): 7-12.

Hussain, M. (2008). Pak-Turkey Relations: On the Common Ties, Alternatives: Turkish Journal of International Relations, 7 (2\&3): 67-85.

Ahmad, N. (1981). Pakistan-Turkey relations, Pakistan Horizon, 34(1): 111, 116-117.

Nawabzada Nasrullah Khan (NNK). (2001). Kashmir Issue and Pakistan's Foreign Policy', Pakistan Horizon, 54(1): 14.

Rahat Shah \& Wang Li. (2020). Rationales behind Pakistan-Turkey relations since September 11, 2001, The Round Table, 109(5): 2-3. DOI: 10.1080/00358533.2020.1819630.

Pervaiz Iqbal Cheema. (1990: 135). Pakistan's Defence Policy, 1947-58, 175 Fifth Avenue, New York, Palgrave Macmillan.

Rahat Shah. (2020). Pakistan- Afghanistan- Turkey Trilateral Summits and its implication for the region, Modern Diplomacy, retrieved on: July 14, 2020 from https://moderndiplomacy.eu/2020/02/24/pakistan-afghanistan-turkey-trilateralsummits-and-its-implication-for-the-region/.

Richard Bernstein. (1983). Move by Cypriots Rejected At U.N, The New York Times, retrieved on: Dec 14, 2019 from https://www.nytimes.com/1983/11/19/world/move-by-cypriotsrejected-at-un.html.

Kaplan, R. D. (2009). Talking to the Taliban Why the Pakistan intelligence agency's close ties with the Taliban should not be condemned, The Atlantic, retrieved on: December 16, 2019 from:https://www.theatlantic.com/magazine/archive/2009/04/talking-to-the-taliban/ 307396/.

Colakoglu, S., \& Sakaoglu, T. (2016). Turkey-Pakistan Relations: Towards Multidimensional Regional Integration. Muslim Perspectives, 1, (2): 01-40.

Pattanaik, S. S. (2002). Pakistan's Kashmir Policy: Objectives and Approaches', Strategic Analysis, 26 (2): 201, 212. 
Shah... Pakistan-Turkey Relations During

Tanvir. S. W. (2011). The Eight Months in the Life of Yahya Kemal', The Middle Eastern Studies, 47 (1), pp-138.

Papadakis, Y., Nicos, P., \& Gisela, W. (2006) Divided Cyprus: Modernity, History and an Island in Conflict, Bloomington, Indiana: Indiana University Press.

Zubeida, H. (1964). Iran, Pakistan and Turkey-Regional Co-Operation for Development, Pakistan Horizon, 17(3): 276-285.

(1960). CAB 134/2344 Official Committee on the Middle East: Meetings 1-5; Papers 1-18', retrieved on: December from https://www.agda.ae/en/catalogue/tna/cab/134/2344.

(1966). Pakistan and the World-Quarterly Survey, Pakistan Horizon, 19 (4): 311.

(1971). Chronology September-November 1971, Pakistan Horizon, 24(4): 127.

(1972). Documents, The India-Pakistan War, 1971, Pakistan Horizon, 25(1): 175, 179.

(1975). Documents, Pakistan Horizon, 28 (2): 140-41.

(1979). Resolution 34/30, PIO, retrieved on: Dec 15, 2019 from https://www.pio.gov.cy /en/\%CF\%88\%CE\%AE\%CF\%86\%CE\%B9\%CF\%83\%CE\%BC\%CE\%B1-34/30-(1979).html.

(1985). DOCUMENTS, Pakistan Horizon, 38 (4): 132-133, 134. 